\title{
Regular occurrence of Thysanoessa inspinata (Crustacea: Euphausiacea) in the Gulf of Alaska
}

\author{
J.A. Lindley* $*^{\ddagger}$, S.D. Batten*, K.O. Coyle ${ }^{\dagger}$ and A.I. Pinchuk ${ }^{\dagger}$ \\ * Sir Alister Hardy Foundation for Ocean Science, The Laboratory, Citadel Hill, Plymouth, PL1 2PB, UK. \\ ${ }^{\dagger}$ Institute of Marine Science, University of Alaska, Fairbanks, AK 99775-7220, USA. ${ }^{\ddagger}$ Corresponding author, e-mail: jal@sahfos.ac.uk
}

Over a period of five years (1997-2002) the euphausiid Thysanoessa inspinata has been recorded in plankton samples from the eastern Gulf of Alaska, as far north as $59^{\circ} \mathrm{N}$. Until recently the northern limit of distribution of the species was assumed to be little further north than $50^{\circ} \mathrm{N}$ but the species is present in oceanic samples off the Alaskan continental shelf throughout the year and occurs regularly in the waters of the eastern Gulf.

\section{INTRODUCTION}

Thysanoessa inspinata was considered to be a morphological variant of $T$. longipes Brandt, 1851 until Nemoto (1963) established its specific status. Brinton (1962) defined the northern limit of the distribution of T. inspinata in the eastern Pacific at about $50^{\circ} \mathrm{N}$. The division of the eastward flowing North Pacific Current into the Alaska Current north of $50^{\circ} \mathrm{N}$ and the southward flowing California Current (e.g. Francis et al., 1998) provides a mechanism for maintaining this division in the eastern North Pacific.

Mauchline \& Fisher (1969) suggested that the species may reach the Aleutian Islands, but the accompanying distribution chart showed the northern limit near to $50^{\circ} \mathrm{N}$ in the eastern Pacific. Motoda \& Minoda (1974), Gorbatenko (2001) and Mackas \& Galbraith (2002) have recorded the species to the north of this.

Coyle \& Pinchuk (2003) noted occurrence of T. inspinata in samples taken in the Gulf of Alaska (GOA) north of $58^{\circ} \mathrm{N}$. Examination of euphausiids from Continuous Plankton Recorder (CPR) tows taken between California and Alaska in 1997 and 2002 have shown regular occurrence of the species north of $50^{\circ} \mathrm{N}$. Here the geographical distributions of the species in these samples and the seasonal and annual timing of the records are described.

\section{MATERIALS AND METHODS}

Thysanoessa inspinata were collected during the North Pacific GLOBEG long-term observation programme (LTOP) in the northern GOA (Weingartner et al., 2002). Sample collection and analysis procedures are presented in detail in Coyle \& Pinchuk (2003), and we describe them briefly here. Zooplankton samples were taken along the Seward Line and in Prince William Sound (PWS) (Figure 1A) from March 1998 through to October 2001 (Table 1A). Euphausiids were collected with a $1-\mathrm{m}^{2}$ MOCNESS (Wiebe et al., 1976) with $500-\mu$ m mesh black nets. The MOGNESS was equipped with a flowmeter positioned outside the mouth of the net, conductivity and temperature probes. The net was fished at night and five oblique samples were collected in $20 \mathrm{~m}$ increments from $100 \mathrm{~m}$ depth to the surface. The samples were preserved in a $10 \%$ formalin-seawater solution. Subsamples taken using a Folsom splitter were examined to identify, sex, stage and count euphausiids. The proportion of the total sample in the subsample varied according to the abundance of zooplankton. Due to uneven spatial distribution of euphausiids, the abundance data were transformed using a power of 0.15 .

Continuous Plankton Recorders (Hardy, 1939) were towed between Long Beach, California and Valdez, Alaska in July 1997 and several times each year from 2000 to 2002. The CPRs are towed at a constant depth of $\sim 7 \mathrm{~m}$ at speeds of $\sim 15 \mathrm{kn}$. The plankton is retained on a band of gauze with a mesh aperture of $270 \mu \mathrm{m}$ which is wound into a storage tank where it is preserved with formalin. The gauze is divided into sections, each containing the plankton retained from $3 \mathrm{~m}^{3}$ of water during ten nautical miles of tow (Batten et al., 2003). Every fourth sample was analysed, except over the Alaskan continental shelf where every sample was analysed. In routine analysis total numbers of furcilias and later stages of euphausiid are recorded and counted but not identified to species. An extreme El Niño event occurred in 1997-1998 with associated high temperatures in the north-western Pacific (Hare \& Mantua, 2000), but subsequently temperatures have been lower. The samples taken in 1997 and in 2002, the year for which there was the most extensive sampling when the work was initiated, were selected for re-examination to provide data for contrasting years. The samples in which euphausiids were recorded have been re-examined and the furcilias and later stages have been identified, where possible, to species. As the furcilias of T. inspinata have not been described, only the post-larval stages have been counted, but 110 specimens $(5 \%$ of total) were referred to 'Thysanoessa spp. furcilia'. The distribution of analysed samples taken in 1997 and 2002 is shown in Figure 1B. The samples were allocated to four geographical regions, the Alaskan shelf (north of $59^{\circ} \mathrm{N}$ ), the Californian slope region (south of $42^{\circ} \mathrm{N}$ ) and northern and southern oceanic areas with a boundary at $50^{\circ} \mathrm{N}$, an approximation 

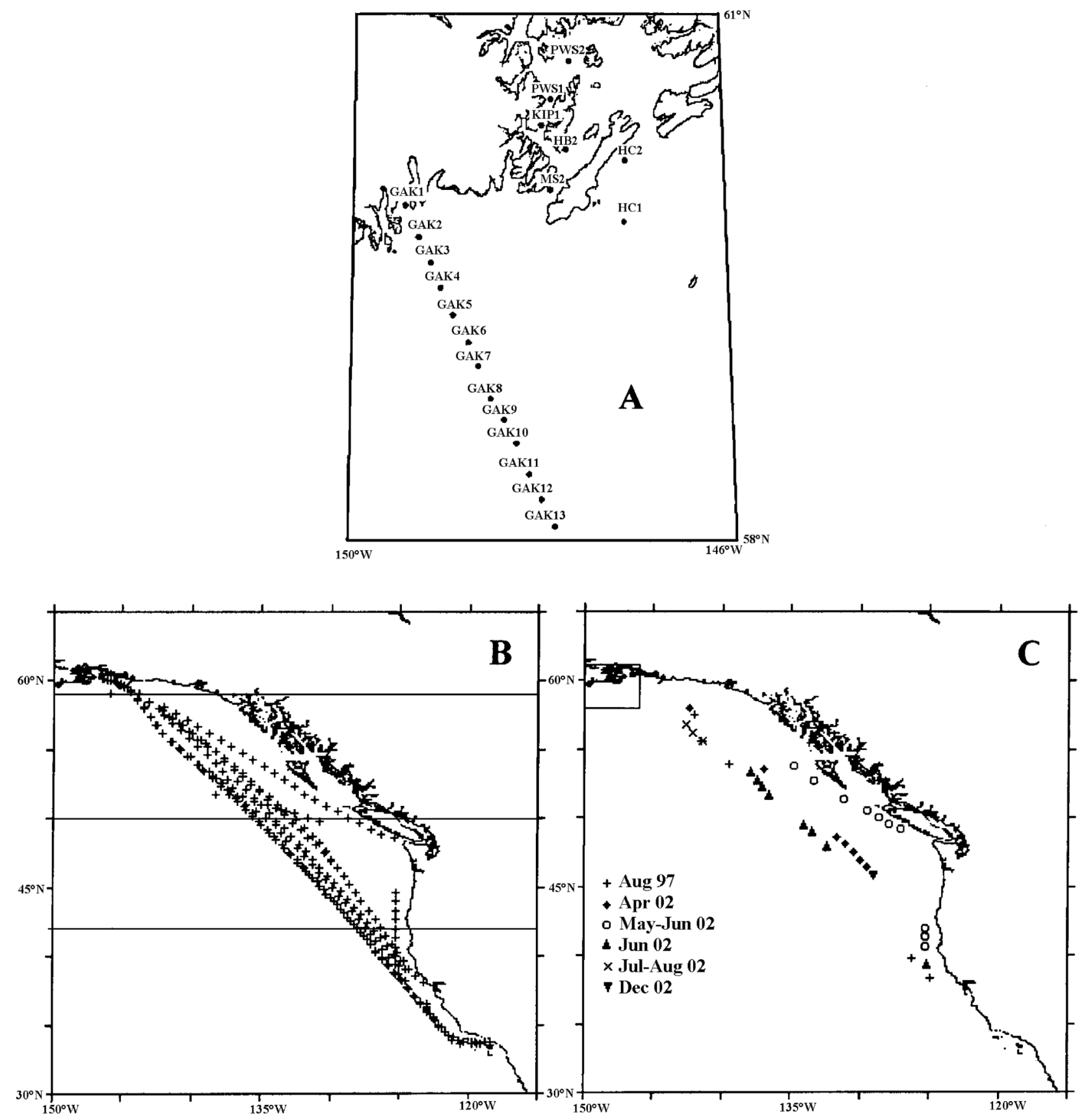

Figure 1. (A) Station locations for the northern Gulf of Alaska GLOBEC project; (B) positions of CPR samples taken between California and Alaska in 1997 and 2002 and the latitudinal subdivisions of the tows; and (C) occurrences of Thysanoessa inspinata in CPR samples shown in Figure 1B. The box, top left, shows the boundaries of Figure 1A.

to the latitude of the division between the northward flowing Alaska current and the southward flowing California current. The dates of sampling and numbers of samples taken in these areas are given in Table 1B.

\section{RESULTS}

Thysanoessa inspinata were usually not abundant in the GLOBEC monitoring stations, but were found consistently in samples from stations located near the shelf break and seaward in the Alaska Current (Figure 2A). Occasionally they were observed up to $59^{\circ} \mathrm{N}$ (Station GAK7) but they were virtually absent from the inner shelf stations. There was no evidence of significant interannual variability of abundance of adults, but abundance of juveniles was significantly lower in 2001 than in previous years (Figure 2B). Females with attached spermatophores and males occurred only in March through May, suggesting spawning during this period. In contrast, few juveniles were recorded in March, but they occurred in substantial numbers from July through October (Figure 2C).

In the CPR samples, Euphausia pacifica Hansen, 1911 was the dominant euphausiid, $(67.2 \%$ of specimens $)$ with Thysanoessa spinifera Holmes, 1900 next (14.7\%). Thysanoessa 

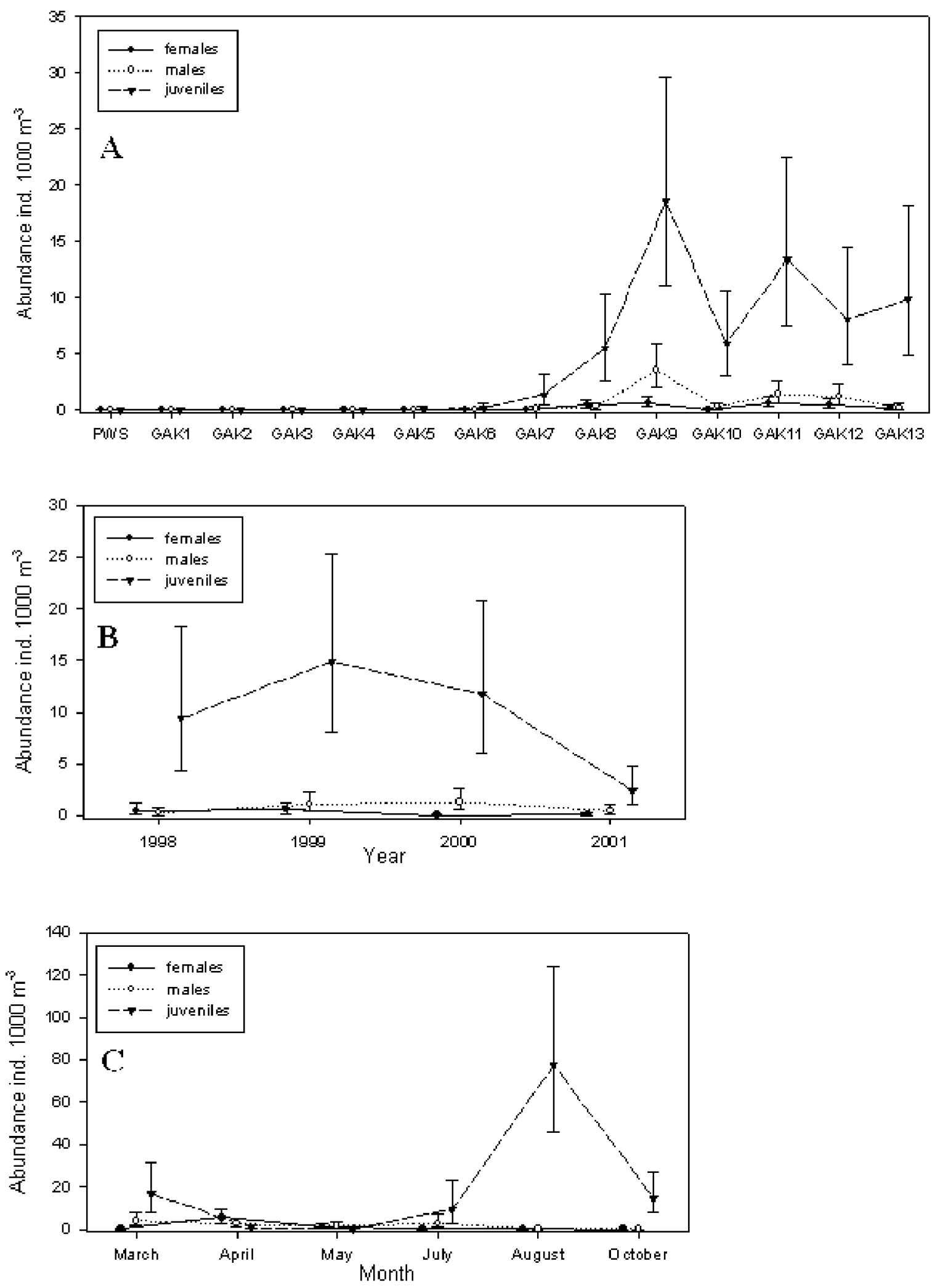

Figure 2. Thysanoessa inspinata sample means and $95 \%$ confidence intervals: (A) distribution of along the Seward Line and in PWS in 1998-2001; (B) interannual variability of $\mathcal{T}$. inspinata abundance on the outer shelf in the northern Gulf of Alaska (Stations GAK7-GAK13); and (C) seasonal variability of T. inspinata abundance on the outer shelf in the northern Gulf of Alaska.

inspinata was the third most abundant species at $11.3 \%$ of the total. Thysanoessa longipes occurred only in the $50-59^{\circ} \mathrm{N}$ zone where it accounted for $2.6 \%$ of euphausiids. The percentage composition of the counts in each of four latitudinal zones is listed in Table 2. The records of Nyctiphanes simplex include one in December 2002 at $49^{\circ} 50^{\prime} \mathrm{N} 132^{\circ} 31^{\prime} \mathrm{W}$, slightly further north of the range described by Tanasichuk \& Cooper (2002). The distribution of records of $T$. inspinata in the samples is shown in Figure 1C. Only small numbers of this species were taken in July 1997, the most northerly at $55^{\circ} 34^{\prime} \mathrm{N}$. In April 2002, most of the records of T. inspinata were between 
Table 1. Sampling in the GLOBEC long-term observation programme (LTOP) and Continuous Plankton Recorder (CPR) tows between California and Alaska.

\begin{tabular}{lllllll}
\hline $\begin{array}{l}\text { A. GLOBEC LTOP cruises. } \\
\text { Year }\end{array}$ & Mar & Apr & May & July & Aug & Oct \\
\hline 1998 & HX203 & HX205 & HX208 & HX211 & & HX213 \\
1999 & HX217 & HX218 & HX219 & & HX223 & HX225 \\
2000 & HX228 & HX230 & HX231 & HX246 & HX248 & HX237 \\
2001 & HX239 & HX241 & HX243 & & & HX252
\end{tabular}

B. CPR samples analysed in four bands of latitude.

2002

\begin{tabular}{|c|c|c|c|c|c|c|c|c|}
\hline & $\begin{array}{l}21 \mathrm{Jul}- \\
6 \mathrm{Aug}\end{array}$ & 7-10 April & $\begin{array}{l}28 \text { May- } \\
6 \text { Jun }\end{array}$ & 16-24 Jun & $\begin{array}{l}29 \mathrm{Jul}- \\
2 \mathrm{Aug}\end{array}$ & $21-23$ Oct & $\begin{array}{l}31 \text { Oct- } \\
2 \text { Nov }\end{array}$ & 7-9 Dec \\
\hline$>59^{\circ} \mathrm{N}$ & 3 & 7 & & & 3 & 7 & & \\
\hline $50-59^{\circ} \mathrm{N}$ & 16 & 16 & 18 & 14 & 16 & 14 & 6 & 15 \\
\hline $42-50^{\circ} \mathrm{N}$ & 16 & 14 & 8 & 14 & 14 & 1 & 14 & 11 \\
\hline$<42^{\circ} \mathrm{N}$ & 17 & 7 & 17 & 13 & 13 & & 5 & \\
\hline
\end{tabular}

Table 2. Euphausiacea in Continuous Plankton Recorder samples (1997 and 2002) in four latitudinal zones shown in Figure 1B (Area). Percentages of Euphausia pacifica, Thysanoessa inspinata, T. longipes, T. spinifera and 'Others' in each region, the total numbers and the numbers of samples are given.

\begin{tabular}{lcccccrr}
\hline Area & E. pacifica & T. inspinata & T. longipes & T. spinifera & Others & Total & Samples \\
\hline$>59^{\circ} \mathrm{N}$ & 50.0 & 0.0 & 0.0 & 40.0 & 10.0 & 10 & 20 \\
$50-59^{\circ} \mathrm{N}$ & 41.9 & 18.6 & 2.6 & 29.3 & 9.8 & 883 & 122 \\
$42-50^{\circ} \mathrm{N}$ & 52.9 & 19.1 & 0.0 & 14.0 & 14.0 & 388 & 78 \\
$<42^{\circ} \mathrm{N}$ & 96.8 & 1.2 & 0.0 & 1.0 & 1.1 & 936 & 68 \\
\hline
\end{tabular}

'Others' includes Nematoscelis difficilis Hansen, 1911, Nyctiphanes simplex, Thysanoessa inermis (Krøyer, 1846) and furcilias of Thysanoessa spp. that could not be referred to species.

$46^{\circ} \mathrm{N}$ and $49^{\circ} \mathrm{N}$ but the most northerly occurred in a sample at $57^{\circ} 56^{\prime} \mathrm{N}$, the highest latitude at which the species has been recorded in CPR samples. In succeeding months the main concentrations of $T$. inspinata were progressively further north than in April occurring from $55^{\circ}$ to $57^{\circ} \mathrm{N}$ between 29 July and 2 August. There were no records of the species in the October and November tows and only one in December 2002.

\section{DISCUSSION}

In the GOA shelf waters there are two major currents, the Alaska Current which flows at or near the shelf break and is transformed into the swifter and narrower Alaskan Stream in the north-western GOA (Weingartner et al., 2002), and the Alaska Coastal Current, a buoyancy driven low-salinity current generated by freshwater discharge and cyclonic wind stress (Royer, 1981; Johnson et al., 1988; Stabeno et al., 1995) within 20 to $50 \mathrm{~km}$ of shore (Royer, 1998). In addition to the main currents, the rugged topography and strong semidiurnal tides generate numerous eddies and meanders including large Haida eddies. These influence the shelf-slope exchange of water mass properties and biota including the distribution of zooplankton along the shelf (Okkonen et al., 2001) and provide a mechanism for transport of Thysanoessa inspinata (Mackas \& Galbraith, 2002).
Our data shows that T. inspinata in the GOA inhabits the Alaska Current and avoids the Alaska Coastal Current. It is also transported into the southern Bering Sea by the northward flowing branches of the Alaskan Stream (Motoda \& Minoda, 1974). Gorbatenko (2001) recorded T. inspinata in 1998 from the north-western Bering Sea. Apparently, the species has been transported by the Aleutian North Slope Current and the Bering Slope Current, which originates in the eastern Aleutians (Stabeno et al., 1995; Hermann et al., 2002). Nemoto \& Kamada (1980) and Taki \& Kotani (1994) recorded Thysanoessa inspinata in cold waters underlying the Kuroshio but not in the warmer northward flowing Kuroshio. Thus, the records of $\mathcal{T}$. inspinata listed above, in addition to those from our work suggest that the species routinely occurs in the Alaska Current/Alaskan Stream/ Oyashio current system, by which it can be transported across the North Pacific from the American coast to Japan and into the Bering Sea. Therefore the actual range of T. inspinata extensively overlaps that of its sibling T. longipes, and its northern limits resemble those of Euphausia pacifica (Brinton et al., 2000).

In the waters off Vancouver Island there was a cumulative shift to more 'southerly' zooplankton through the 1990s (Mackas et al., 2001). Hollowed et al. (2001) show that prolonged periods of warm conditions at high latitudes have been associated with periods of highly 
frequent El Niño events. Numbers of T. inspinata in the LTOP samples have been declining, which may be related to lower temperature since the end of the El Niño event in 1997-1998 (Hare \& Mantua, 2000). If the temperatures remain at the lower level it will be interesting to see whether the species will persist in the area. It will also be interesting to compare the future records of the oceanic T. inspinata with those of Nyctiphanes simplex, which occurs mainly in coastal waters, the northward spread of which has been linked to the El Niño southern oscillation, particularly the 1998 event (Tanasichuk \& Cooper, 2002).

Kuznetsova $(1980,1994)$ concluded that T. inspinata has a two-year life span and spawns once a year in late spring. In the northern GOA our results are consistent with a discrete spring spawning event in the GOA. It is unclear if T. inspinata breeds in the northernmost areas of its range in the Bering Sea.

Sampling for the GOA programme was carried out on the RV 'Alpha Helix' with technical support from the captain, crew and ship's technicians. Aid in sample processing and data entry was provided by Chris Stark, Janet Ballek and Elizabeth Stockmar. The monitoring programme in the northern GOA was funded by US GLOBEC award no. NA67RJ0147AMD7. The US GLOBEC contribution no. is 436.

We thank the Polar Tankers Inc. and the masters and crew of the 'Polar Alaska' and the 'Polar Independence' which towed the CPRs and the survey team for maintaining the survey and processing and analysing the samples. The collection and analysis of CPR data was funded by a grant through the North Pacific Marine Research Institute at the Alaska SeaLife Center and through the Exxon Valdez Oil Spill Trustee Council's GEM programme, project no. 020624. We gratefully acknowledge their support.

\section{REFERENCES}

Batten, S.D. et al., 2003. CPR sampling: the technical background, materials and methods, and issues of consistency and comparability. Progress in Oceanography, 58, 193-215.

Brinton, E., 1962. The distribution of Pacific euphausiids. Bulletin of the Scripps Institute of Oceanography, 8, 51-270.

Brinton, E., Ohman, M.D., Townsend, A.W., Knight, M.D. \& Bridgeman, A.L., 2000. Euphausiids of the world ocean. ETI World Biodiversity Database CD-ROM Series. SpringerVerlag Electronic Media.

Coyle, K.O. \& Pinchuk, A.I., 2003. Annual cycle of zooplankton abundance, biomass and production on the northern Gulf of Alaska shelf, October 1997 through October 2000. Fisheries Oceanography, 12, 327-338.

Francis, R.C., Hare, S.R., Hollowed, A.B. \& Wooster, W.S., 1998. Effects of interdecadal climate variability on the oceanic ecosystems of the NE Pacfic. Fisheries Oceanography, 7, 1-21.

Gorbatenko, K.M., 2001. Vertical distribution of zooplankton in the northwestern deep part of Bering Sea in the spring period. Izvestia TINRO, 128, 799-809. [In Russian.]

Hardy, A.C., 1939. Ecological investigations with the continuous plankton recorder: object, plan and methods. Hull Bulletins of Marine Ecology, 1, 1-57.

Hare, S.R. \& Mantua, N.J., 2000. Empirical evidence for North Pacific regime shifts in 1977 and 1989. Progress in Oceanography, 47, 103-145.

Hermann, A.J., Stabeno, P.J., Haidvogel, D.B. \& Musgrave, D.L., 2002. A regional tidal/subtidal circulation model of the southeastern Bering Sea: development, sensitivity analyses and hindcasting. Deep-Sea Research II, 49, 5945-5967.
Hollowed, A.B., Hare, S.R. \& Wooster, W.S., 2001. Pacific Basin climate variability and patterns of Northeast Pacific marine fish production. Progress in Oceanography, 49, 257-282.

Johnson, W.R., Royer, T.G. \& Luick, J.L., 1988. On the seasonal variability of the Alaska Coastal Current. Fournal of Geophysical Research, 93, 12423-12437.

Kuznetsova, N.A., 1980. The state of reproductive systems in some mass euphausiid species of the Kuroshio area in different seasons. Izvestia TINRO, 104, 64-69. [In Russian.]

Kuznetsova, N.A., 1994. Some biological features of Thysanoessa inspinata (Nemoto, 1963) in subarctic waters of the Northwest Pacific. Izvestia TINRO, 116, 199-205. [In Russian.]

Mackas, D.L. \& Galbraith, M., 2002. Zooplankton distribution and dynamics in a North Pacific eddy of coastal origin. 1. Transport and loss of continental margin species. Fournal of Oceanography, 58, 725-738.

Mackas, D.L., Thomson, R.E. \& Galbraith, M., 2001. Changes in the zooplankton community of the British Columbia continental margin, 1985-1999, and their covariation with oceanographic conditions. Canadian Fournal of Fisheries and Aquatic Sciences, 58, 685-702.

Mauchline, J. \& Fisher, L.R., 1969. The biology of euphausiids. Advances in Marine Biology, 7, 1-454.

Motoda, S. \& Minoda, T., 1974. Plankton of the Bering Sea. In Oceanography of the Bering Sea with emphasis on renewable resources (ed. D.W. Hood and E.J. Kelley), pp. 207-241. Institute of Marine Science, University of Alaska, Fairbanks, Occasional Publications, no. 2.

Nemoto, T., 1963. A new species of Euphausiacea, Thysanoëssa inspinata from the North Pacific. Fournal of the Oceanographical Society of Japan, 19, 41-47.

Nemoto, T. \& Kamada, K., 1980. Distribution and feeding ecology of euphausiids in the Kuroshio region. In The Kuroshio 4. Proceedings of the fourth symposium for the co-operative study of the Kuroshio and adjacent regions, the Fapan academy, Tokyo, 14-17 February, 1979, pp. 649-650. IOC, Paris: Japanese National Committee for UNESCO.

Okkonen, S.R., Jacobs, G.A., Metzger, E.J., Hurlburt, H.E. \& Shriver, J.F., 2001. Mesoscale variability in the boundary currents of the Alaska Gyre. Continental Shelf Research, 21, 1219-1236.

Royer, T.C., 1981. Baroclinic transport in the Gulf of Alaska. Part II. Freshwater driven coastal current. Fournal of Marine Research, 38, 251-266.

Royer, T.C., 1998. Coastal processes in the northern North Pacific. In The sea. Ideas and observations on progress in the study of the seas. Vol. 11. The global coastal ocean: regional studies and synthesis. (ed A.R. Robinson and K.H. Brink), pp. 395-414. New York: John Wiley \& Sons, Inc.

Stabeno, P.J., Reed, R.K. \& Schumacher, J.D., 1995. The Alaska Coastal Current: continuity of transport and forcing. Fournal of Geophysical Research, 100, 2477-2485.

Taki, K. \& Kotani, Y., 1994. Distribution in spring of some developmental stages of euphausiids in the coastal waters off Onagawa, Miyagi Prefecture. Bulletin of the Tohoku Regional Fisheries Research Laboratory, 56, 91-104.

Tanasichuk, R.W. \& Cooper, C., 2002. A northern extension of the range of the euphausiid Nyctiphanes simplex into Canadian waters. Fournal of Crustacean Biology, 22, 206-209.

Wiebe, P.H., Burt, K.H., Boyd, S.H. \& Morton, A.W., 1976. A multiple opening/closing net and environmental sensing system for sampling zooplankton. Fournal of Marine Research, 34, 313-325.

Weingartner, T.J. et al., 2002. The Northeast Pacific GLOBEC program: coastal Gulf of Alaska. Oceanography, 15, 48-63.

Submitted 20 Fanuary 2004. Accepted 7 Fuly 2004. 